\title{
Physical inactivity and obesity: a vicious circle
}

Citation for published version (APA):

Pietilainen, K. H., Kaprio, J., Borg, P. A. J., Plasqui, G., Yki Jarvinen, H., Kujala, U. M., Rose, R. J., Westerterp, K. R., \& Rissanen, A. (2008). Physical inactivity and obesity: a vicious circle. Obesity, 16(2), 409-14. https://doi.org/10.1038/oby.2007.72

Document status and date:

Published: 01/01/2008

DOI:

10.1038/oby.2007.72

Document Version:

Publisher's PDF, also known as Version of record

Document license:

Taverne

Please check the document version of this publication:

- A submitted manuscript is the version of the article upon submission and before peer-review. There can be important differences between the submitted version and the official published version of record.

People interested in the research are advised to contact the author for the final version of the publication, or visit the DOI to the publisher's website.

- The final author version and the galley proof are versions of the publication after peer review.

- The final published version features the final layout of the paper including the volume, issue and page numbers.

Link to publication

\footnotetext{
General rights rights.

- You may freely distribute the URL identifying the publication in the public portal. please follow below link for the End User Agreement:

www.umlib.nl/taverne-license

Take down policy

If you believe that this document breaches copyright please contact us at:

repository@maastrichtuniversity.nl

providing details and we will investigate your claim.
}

Copyright and moral rights for the publications made accessible in the public portal are retained by the authors and/or other copyright owners and it is a condition of accessing publications that users recognise and abide by the legal requirements associated with these

- Users may download and print one copy of any publication from the public portal for the purpose of private study or research.

- You may not further distribute the material or use it for any profit-making activity or commercial gain

If the publication is distributed under the terms of Article $25 \mathrm{fa}$ of the Dutch Copyright Act, indicated by the "Taverne" license above, 


\title{
Physical Inactivity and Obesity: A Vicious Circle
}

\author{
Kirsi H. Pietiläinen ${ }^{1-3}$, Jaakko Kaprio ${ }^{2,4}$, Patrik Borg ${ }^{5}$, Guy Plasqui ${ }^{6}$, Hannele Yki-Järvinen ${ }^{3}$, \\ Urho M. Kujala ${ }^{7}$, Richard J. Rose ${ }^{2,8}$, Klaas R. Westerterp ${ }^{6}$ and Aila Rissanen ${ }^{1}$
}

Objective: Physical activity (PA) begins to decline in adolescence with a concomitant increase in weight. We hypothesized that a vicious circle may arise between decreasing PA and weight gain from adolescence to early adulthood.

Methods and Procedures: PA and self-perceived physical fitness assessed in adolescents (16-18 years of age) were used to predict the development of obesity $\left(B M I \geq 30 \mathrm{~kg} / \mathrm{m}^{2}\right.$ ) and abdominal obesity (waist $\geq 88 \mathrm{~cm}$ in females and $\geq 102 \mathrm{~cm}$ in males) at age 25 in 4,240 twin individuals (90\% of twins born in Finland, 1975-1979). Ten 25-year-old monozygotic (MZ) twin pairs who were discordant for obesity (with a $16 \mathrm{~kg}$ weight difference) were then carefully evaluated for current PA (using a triaxial accelerometer), total energy expenditure (TEE, assessed by means of the doubly labeled water (DLW) method), and basal metabolic rate (BMR, assessed by indirect calorimetry).

Results: Physical inactivity in adolescence strongly predicted the risk for obesity (odds ratio (OR) 3.9, 95\% confidence interval (CI) 1.4-10.9) and abdominal obesity $(4.8,1.9-12.0)$ at age 25 , even after adjusting for baseline and current BMI. Poor physical fitness in adolescence also increased the risk for overall obesity (5.1, 2.0-12.7) and abdominal obesity $(3.2,1.5-6.7)$ in adulthood. Physical inactivity was both causative and secondary to the development of obesity discordance in the MZ pairs. TEE did not differ between the MZ co-twins. PA was lower whereas BMR was higher in the obese co-twins.

Discussion: Physical inactivity in adolescence strongly and independently predicts total (and especially) abdominal obesity in young adulthood, favoring the development of a self-perpetuating vicious circle of obesity and physical inactivity. Physical activity should therefore be seriously recommended for obesity prevention in the young.

Obesity (2008) 16, 409-414. doi:10.1038/oby.2007.72

\section{INTRODUCTION}

It is well documented that physical activity (PA) begins to decline in adolescence (1) with concomitant increase in weight (2). Whether these trends continue in the transitional period from adolescence to adulthood, a time critical for the development of obesity (3), is not clear (4). The evidence of a relationship between physical inactivity in adolescence and obesity in adulthood has been weak or non-existent in the few published longitudinal studies (4-8). Very little is known about the relationship between PA and abdominal obesity. A long-term follow up of 5,700 Finnish men and women failed to show a relationship between adolescent activity and later obesity, but an increased risk for abdominal obesity, independent of current BMI, was documented for women who became inactive after adolescence (6). Because both PA (9) and body size (10) are influenced by genetic factors, it is possible that individuals not undertaking exercise and then gaining weight are genetically predisposed to do so.
Disentangling genetic effects from life-style has not been possible in previous studies.

Once obesity becomes established in an individual, the energy balance changes. Data on 319 adults from the United Kingdom indicate that total energy expenditure (TEE, assessed by the doubly labeled water (DLW) method), basal metabolic rate (BMR), and AEE (activity-induced energy expenditure) are increased in obesity due to the larger body size (11). According to these results, PA is not changed in obesity (11). Other studies suggest the contrary: obese subjects are less active and expend less energy in PA than do lighter subjects $(12,13)$. About $40 \%$ of the inter-individual variation of the various components of energy expenditure in humans is explained by genetic factors (14), in part because of the shared genetic background of energy expenditure and body size (15). To better understand the relationships between obesity and energy balance, it is important to distinguish genetic effects from those that are acquired by weight gain. 
In this study, we assessed the role of persistent PA vs. inactivity in adolescence (16-18 years) on the development of obesity and abdominal obesity in adulthood (at the age of 25) in a longitudinal population-based sample of twins. Further, we chose from this sample a rare group of monozygotic (MZ) twin pairs discordant for obesity in young adulthood to determine the effects of acquired obesity on various components of energy expenditure.

\section{METHODS AND PROCEDURES Study populations}

The Twin Cohort Study. Participants were recruited from a population-based, longitudinal study of five consecutive birth cohorts (1975-1979) of Finnish twins (the FinnTwin16 cohort) (16). All twins had been sent a questionnaire in adolescence at $16,17,18$, and again as adults at 22-27 (mean 25) years of age. Response rates were high (83-97\%) on all occasions. We included healthy twins who had responded to all four questionnaires (4,240 individuals, including 1,870 twin pairs).

MZ Twin Study. Of the $658 \mathrm{MZ}$ pairs in the FinnTwin16 cohort, 14 reported a BMI difference of at least $4 \mathrm{~kg} / \mathrm{m}^{2}$ in the adult questionnaire, with one twin being non-obese (BMI $\sim 25 \mathrm{~kg} / \mathrm{m}^{2}$ ), and the other obese (BMI $\left.\sim 30 \mathrm{~kg} / \mathrm{m}^{2}\right)(17,18)$. Five male and five female pairs (measured BMI differences from 3.8 to $10.1 \mathrm{~kg} / \mathrm{m}^{2}$ ) agreed to participate in the clinical protocol described below. We also studied nine concordant MZ pairs with a reported BMI difference of $<2 \mathrm{~kg} / \mathrm{m}^{2}$ (measured BMI differences from 0.0 to $2.3 \mathrm{~kg} / \mathrm{m}^{2}$ ) as a reference $\mathrm{MZ}$ twin sample $(17,18)$. All twins were healthy and weight-stable. Females were scheduled to attend during the follicular phase of their menstrual circle.

The study protocols were approved by the institutional review boards of Indiana University, Bloomington, the University of Helsinki, and the University Central Hospital of Helsinki, Finland. All participants in the clinical study gave written informed consent.

\section{Obesity}

Weight $(\mathrm{kg})$ and height $(\mathrm{cm})$ were self-reported in all questionnaires and used to compute BMI $\left(\mathrm{kg} / \mathrm{m}^{2}\right)$. In adolescents up to the age of 18 years, obesity was classified using age- and sex-specific BMI reference data (19), and in adults, using a BMI cut point of $30 \mathrm{~kg} / \mathrm{m}^{2}$. At age 25, waist circumference was self-measured using a tape measure supplied with the questionnaire. Abdominal obesity was defined by cut off points of $88 \mathrm{~cm}$ for women and $102 \mathrm{~cm}$ for men (20). The comparability of self-reported and measured data was ascertained in 566 twins on average 663 days after the completion of the questionnaire. The intraclass correlation for BMI was 0.94 and for waist circumference 0.73 . The $\kappa$ value for obesity was 0.66 (95\% confidence interval (CI) $0.58-0.74)$ and for abdominal obesity $0.60(0.52-0.69)$.

In the clinical study, adolescent growth charts were obtained from health records (17) and adult weight, height and waist measured. Fat mass, fat-free mass, and percent whole body fat was assessed by dualenergy X-ray absorptiometry (21) (Lunar Prodigy, Madison, WI, software version 2.15).

\section{PA}

The frequency of leisure-time PA was assessed by a structured question included in all four mailed questionnaires with the following response alternatives: "not at all, less than once a month, 1-2 times a month, about once a week, 2-3 times a week, 4-5 times a week, and every day" (22). Those reporting the two highest alternatives in all adolescent questionnaires at age 16-18 were defined as persistently active, and those who exercised 1-2 times a month or less as persistently inactive, and others as occasionally active at baseline (22). The second question asked for the subject's own perception of his or her physical fitness. Alternatives were "very good, fairly good, satisfactory, rather poor, very poor" (22). The two first and two last alternatives were combined to yield good, satisfactory and poor fitness classes. Persistency of fitness was grouped into five classes: (i) those reporting good fitness at age 16-18 were defined as persistently fit, (ii) those reporting satisfactory fitness during these baseline time points as persistently satisfactorily fit, and (iii) those reporting poor fitness as persistently unfit. In addition, if the subject's fitness improved or declined over the baseline, from 16 to 18 years, (s)he was grouped into (iv) increasing or (v) decreasing fitness classes, respectively. The validity of the questionnaire-reported PA and fitness was tested in a separate sub-sample (16 male pairs) (22). The frequency of leisure-time PA from the questionnaires correlated with leisure time PA during the previous 12 months in an interview $(r=0.52$, $P=0.002)$ and with maximal oxygen uptake $\left(\mathrm{VO}_{2 \max }\right)(r=0.45, P=$ $0.010)$. The respective correlations for self-perceived physical fitness were $(r=0.62, P<0.001)$ and $(r=0.47, P=0.006)$.

For the MZ twins participating in the clinical protocol, the frequency of leisure-time PA from the questionnaires at $16-25$ years was additionally converted into a semi-continuous measure describing days per year with PA, with values of $0,6,18,52,130,230$, and 360 days per year. The original fitness question grouped into good, satisfactory or poor was used to assess self-perceived fitness prospectively from 16 to 25 years. As part of the clinical protocol at 25 years, PA of the MZ twins was ascertained by several methods. Their current PA was assessed by tri-axial accelerometers (23), a questionnaire (Baecke et al. (24)) and an interview (Kriska et al. (25)), which also provides PA assessment retrospectively between 12 and 18 years. In the interview, each activity was weighted by its relative metabolic cost, thereby deriving metabolic equivalent-hours (1-h energy expenditure for an individual at rest) per week as the final unit of expression (25). Activity counts of a tri-axial accelerometer for movement registration (Tracmor, Philips Research, Eindhoven, The Netherlands) were used for seven consecutive days during waking hours, except during bathing (23). The movement was expressed as counts per day by adding body accelerations in anteroposterior, mediolateral and vertical axes. The tri-axial accelerometer has been validated against DLW (23). Accelerometers were used by the eight discordant pairs who were also measured by means of DLW (vide infra). Unfortunately, accelerometer data for four individuals (from three full pairs) was lost during transportation, leaving us with only five discordant twin pairs for this analysis.

\section{Energy expenditure}

In the clinical study, the BMR was measured in all pairs after an overnight fast using the Deltatrac Metabolic Monitor (Datex, Helsinki, Finland) (26). TEE was measured in eight (five male, three female) discordant pairs with DLW for 14 consecutive days following the Maastricht protocol (27). AEE was calculated as $0.9 \times$ TEE-BMR, with a diet-induced thermogenesis of $10 \%$ assumed. The PA level (PAL) was calculated as TEE/BMR (28).

\section{Statistics}

In the whole cohort, the relationship between adolescent PA and the adult obesity outcome was quantified using logistic regression models with adjustment for sex and baseline BMI at 16-18 years. Both genders were combined, as there were no significant sex effects in the models. The odds ratio (OR) for adult abdominal obesity was further adjusted for adult BMI. CIs were corrected for clustered sampling of co-twins within pairs (29).

In the clinical substudy, Wilcoxon matched pairs signed ranks test was used to compare the obese and the non-obese co-twins. ANOVA for repeated measures in matched individuals was used in longitudinal analyses of the frequency of PA (Figure 1). Symmetry test was used to test the longitudinal trends in the fitness categories between 16 and 25 years. Spearman's correlation and multiple linear regression analyses of intra-pair differences (all MZ pairs included) were used to assess the relationships between PA, body composition and energy expenditure independent of genetic influences. For individual twins, Pearson's correlations and linear regressions were corrected for clustered sampling of co-twins within pairs (29). Data are mean \pm s.e. 

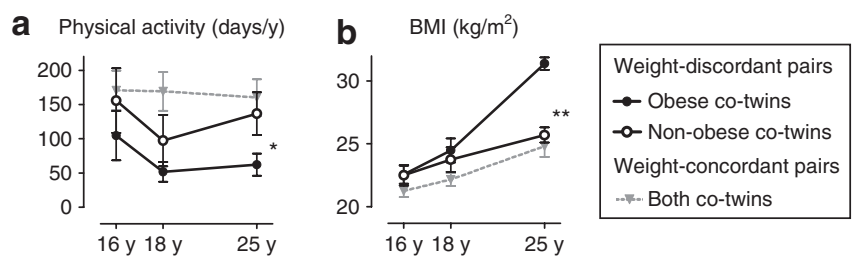

Figure 1 (a) The frequency of leisure-time physical activity (mean (s.e.) days per year from prospective questionnaires) and (b) mean (s.e.) BMI (from health registries) from 16 to 25 years in 10 weight-discordant and 9 weight-concordant monozygotic (MZ) twin pairs. ${ }^{*} P<0.05,{ }^{* *} P<0.001$.

\section{RESULTS}

Physical inactivity as a predictor of obesity in the Twin Cohort Study

Obesity in adolescence was rare $(0.7 \%$ at 16 years, $0.7 \%$ at 17 years, and $1.1 \%$ at 18 years). At the age of 25 years, $4 \%$ of the twins were obese and $8 \%$ had abdominal obesity. The risk of becoming obese in adulthood was 3.9 (95\% CI 1.4-10.9) fold higher among the physically inactive adolescents compared to those who were physically active (Table 1 ). The risk for abdominal obesity in adulthood was almost fivefold (4.8, 1.9-12.0) even after adjusting for adult BMI (Table 1). Those who perceived themselves as persistently unfit in adolescence had a marked risk for adult overall $(5.1,2.0-12.7)$ and abdominal obesity $(3.2,1.5-6.7)$ (Table 2$)$. Adult obesity risk was also increased in those whose fitness declined from 16 to 18 years (Table 2).

\section{Physical inactivity and obesity independent of genetic effects in the MZ twins}

In the MZ twin substudy, the co-twins who ultimately became obese (Figure 1, Table 3 ) had been less physically active in adolescence than their non-obese co-twins (Figure 1) (ANOVA $F=5.40, P=0.025)$. During the development of obesity, PA declined further. According to the Kriska interview (25), PA decreased by $51 \%$ from age $12-18$ to age 25 years in the subsequently obese MZ co-twins (Figure 2). Prospectively measured self-perceived fitness declined from 16 to 25 years in the obese co-twins with a borderline significance $(P=0.065)$ but remained unchanged in the non-obese co-twins $(P=0.4)$ (Figure 3$)$. In adulthood, the obese co-twins $(2.6 \pm 0.2)$ were significantly less active than the non-obese co-twins $(3.1 \pm 0.2, P=0.01)$ by the Baecke questionnaire indices (24). This was also confirmed objectively by the accelerometers. The obese co-twins had less than half the activity levels (4.2 $\pm 0.5 \times 10^{9}$ counts per day) of that of their non-obese co-twins $\left(9.7 \pm 2.0 \times 10^{9}\right.$ counts per day, $P=0.04$ ) throughout the study week (Figure 4). An example in Figure 5 illustrates that the obese co-twins had low overall and virtually no high-intensity exercise. Activity counts correlated negatively with fat mass $(r=-0.63, P=0.059)$, but not with fat-free mass $(r=0.19, P=0.27)$ in the twin individuals. In the weight-concordant reference $\mathrm{MZ}$ twin pairs, PA patterns and fitness changed little during adolescence and were similar in the co-twins, as was the development of BMI (Figures 1-3).
Table 1 Odds ratios (ORs and 95\% confidence intervals (Cls)) of obesity and abdominal obesity at 25 years by physical activity at $16-18$ years in the Twin Cohort Study

\begin{tabular}{|c|c|c|c|c|}
\hline & \multicolumn{2}{|c|}{$\begin{array}{c}\text { Obesity }^{\mathrm{a}} \text { at } \\
25 \text { years } \\
(n=4,068)\end{array}$} & \multicolumn{2}{|c|}{$\begin{array}{c}\text { Abdominal } \\
\text { obesity }^{\mathrm{b}} \text { at } \\
25 \text { years } \\
(n=3,982)\end{array}$} \\
\hline & OR & $95 \% \mathrm{Cl}$ & OR & $95 \% \mathrm{Cl}$ \\
\hline \multicolumn{5}{|c|}{ Physical activity at $16-18$ years } \\
\hline Persistently active & 1.0 & & 1.0 & \\
\hline $\begin{array}{l}\text { Occasionally active } \\
\text { Adjusted for sex } \\
\text { and BMl at } \\
\text { 16-18 years } \\
\text { Additionally } \\
\text { adjusted for BMl } \\
\text { at } 25 \text { years }\end{array}$ & 2.04 & $0.98,4.26$ & 2.72 & $1.31,5.65$ \\
\hline $\begin{array}{l}\text { Persistently inactive } \\
\text { Adjusted for sex and } \\
\text { BMl at } 16-18 \text { years } \\
\text { Additionally adjusted } \\
\text { for BMl at } 25 \text { years }\end{array}$ & 3.86 & $\begin{array}{c}1.37 \\
10.89\end{array}$ & $\begin{array}{l}5.71 \\
4.79\end{array}$ & $\begin{array}{l}2.83,11.53 \\
1.92,12.00\end{array}$ \\
\hline
\end{tabular}

${ }^{\mathrm{a} B M l} \geq 30 \mathrm{~kg} / \mathrm{m}^{2}$. b Waist circumference $\geq 88 \mathrm{~cm}$ in females and $\geq 102 \mathrm{~cm}$ in males.

Table 2 Odds ratios (ORs and 95\% confidence intervals (Cls)) of obesity and abdominal obesity at 25 years by participant's own perception of physical fitness at 16-18 years in the Twin Cohort Study

\begin{tabular}{|c|c|c|c|c|}
\hline & \multicolumn{2}{|c|}{$\begin{array}{c}\text { Obesity }^{\mathrm{a}} \text { at } \\
25 \text { years } \\
(n=3,947)\end{array}$} & \multicolumn{2}{|c|}{$\begin{array}{l}\text { Abdominal obesity } \\
\text { at } 25 \text { years } \\
(n=3,866)\end{array}$} \\
\hline & OR & $95 \% \mathrm{Cl}$ & OR & $95 \% \mathrm{Cl}$ \\
\hline \multicolumn{5}{|c|}{ Physical fitness at $16-18$ years } \\
\hline Persistently fit & 1.0 & & 1.0 & \\
\hline $\begin{array}{l}\text { Persistently unfit } \\
\text { Adjusted for sex and } \\
\text { BMl at } 16-18 \text { years } \\
\text { Additionally adjusted } \\
\text { for BMl at } 25 \text { years }\end{array}$ & 5.07 & $2.03,12.67$ & $\begin{array}{l}3.00 \\
3.16\end{array}$ & $\begin{array}{l}1.47,6.00 \\
1.48,6.73\end{array}$ \\
\hline \multicolumn{5}{|l|}{$\begin{array}{l}\text { Persistently satisfactory } \\
\text { fitness }\end{array}$} \\
\hline $\begin{array}{l}\text { Adjusted for sex and } \\
\text { BMl at } 16-18 \text { years } \\
\text { Additionally adjusted } \\
\text { for BMl at } 25 \text { years }\end{array}$ & 1.3 & $0.63,2.67$ & $\begin{array}{l}1.43 \\
1.49\end{array}$ & $\begin{array}{l}0.92,2.22 \\
0.91,2.44\end{array}$ \\
\hline $\begin{array}{l}\text { Increasing fitness } \\
\text { Adjusted for sex and } \\
\text { BMl at } 16-18 \text { years } \\
\text { Additionally adjusted } \\
\text { for BMl at } 25 \text { years }\end{array}$ & 1.42 & $0.74,2.76$ & $\begin{array}{l}1.35 \\
1.27\end{array}$ & $\begin{array}{l}0.89,2.06 \\
0.75,2.15\end{array}$ \\
\hline $\begin{array}{l}\text { Decreasing fitness } \\
\text { Adjusted for sex and } \\
\text { BMl at 16-18 years } \\
\text { Additionally adjusted } \\
\text { for BMl at } 25 \text { years }\end{array}$ & 2.73 & $1.56,4.78$ & $\begin{array}{l}2.22 \\
1.50\end{array}$ & $\begin{array}{l}1.54,3.21 \\
0.98,2.23\end{array}$ \\
\hline
\end{tabular}

${ }^{\mathrm{a}} \mathrm{BMl} \geq 30 \mathrm{~kg} / \mathrm{m}^{2}$. ${ }^{b}$ Waist circumference $\geq 88 \mathrm{~cm}$ in females and $\geq 102 \mathrm{~cm}$ in males.

\section{Energy balance and obesity independent of genetic effects in the MZ twins}

Due to the significantly higher PA of the non-obese co-twins, they reached similar levels of TEE $(11,541 \pm 687 \mathrm{~kJ} /$ day $)$ than 
Table 3 Characteristics of the weight-discordant and weightconcordant monozygotic (MZ) twins

\begin{tabular}{|c|c|c|c|c|}
\hline & \multicolumn{3}{|c|}{$\begin{array}{l}\text { Weight-discordant pairs } \\
\qquad N=10\end{array}$} & \multirow{2}{*}{$\begin{array}{c}\begin{array}{c}\text { Weight- } \\
\text { concordant } \\
\text { pairs } \\
N=9\end{array} \\
\end{array}$} \\
\hline & $\begin{array}{l}\text { Non-obese } \\
\text { co-twins }\end{array}$ & $P$ & $\begin{array}{l}\text { Obese } \\
\text { co-twins }\end{array}$ & \\
\hline Age (years) & $25.6 \pm 0.3$ & & $25.6 \pm 0.3$ & $25.8 \pm 0.4$ \\
\hline Weight (kg) & $73.5 \pm 2.7$ & 0.005 & $89.9 \pm 2.7$ & $74.8 \pm 4.5$ \\
\hline BMI $\left(\mathrm{kg} / \mathrm{m}^{2}\right)$ & $25.7 \pm 0.6$ & 0.005 & $31.4 \pm 0.5$ & $24.8 \pm 1.2$ \\
\hline Waist (cm) & $90 \pm 2$ & 0.003 & $105 \pm 1$ & $86 \pm 4$ \\
\hline Body fat (\%) & $30.5 \pm 2.4$ & 0.005 & $39.5 \pm 1.9$ & $25.9 \pm 3.9$ \\
\hline Fat (kg) & $22.2 \pm 1.5$ & 0.005 & $35.2 \pm 1.3$ & $20.0 \pm 3.5$ \\
\hline Fat free mass (kg) & $48.8 \pm 3.2$ & 0.02 & $51.7 \pm 3.0$ & $52.4 \pm 3.4$ \\
\hline
\end{tabular}

Data are mean \pm s.e.

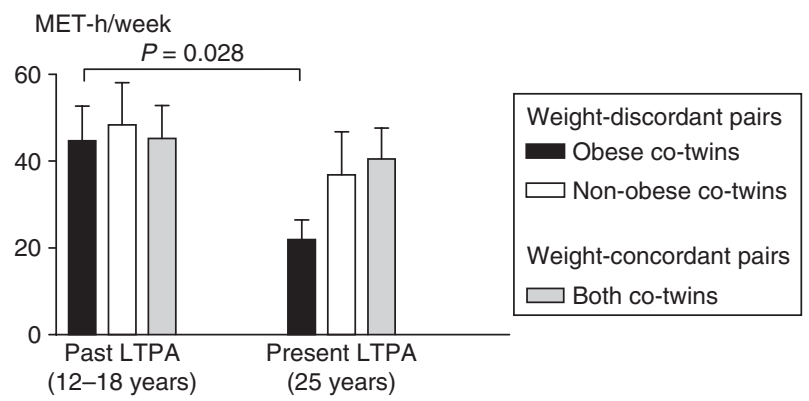

Figure 2 Past and present leisure-time physical activity (LTPA) (from the Kriska interview (25)) in 10 weight-discordant and 9 weight-concordant monozygotic (MZ) twin pairs. Data are mean (s.e.). MET, metabolic equivalent.

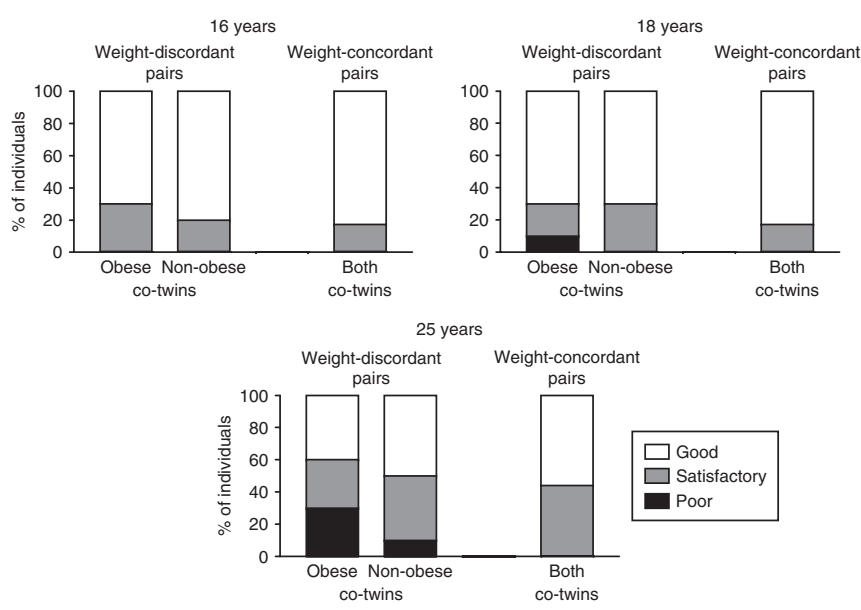

Figure 3 Self-perceived physical fitness from 16 to 25 years in 10 weight-discordant and 9 weight-concordant twin pairs.

the much heavier obese co-twins $(12,404 \pm 351 \mathrm{~kJ} / \mathrm{day}, P=$ 0.21). AEE and PAL were also similar between the co-twins (data not shown), whereas AEE/kg body weight showed a nonsignificant trend for lower activity in the obese $(45 \pm 19 \mathrm{~kJ} / \mathrm{kg})$ as compared with the non-obese co-twins (54 $\pm 14 \mathrm{~kJ} / \mathrm{kg})$. BMR was $605 \mathrm{~kJ}$ higher in the obese $(6,821 \pm 300 \mathrm{~kJ} /$ day $)$ than in the non-obese co-twins $(6,217 \pm 346 \mathrm{~kJ} / \mathrm{day}, P=0.009)$. However,

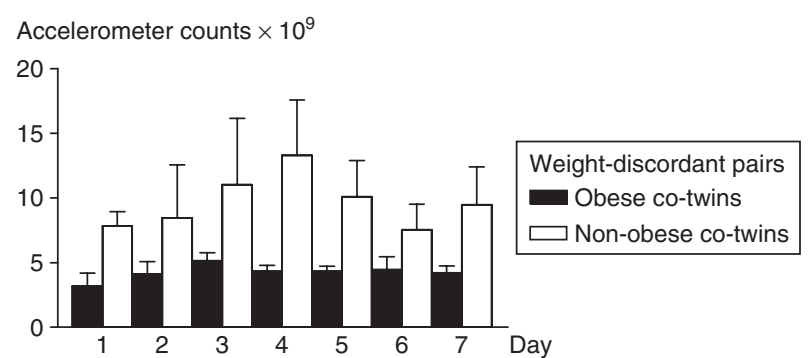

Figure 4 Daily mean (s.e.) accelerometer counts from the 1-week measuring period in five weight-discordant monozygotic (MZ) twin pairs.

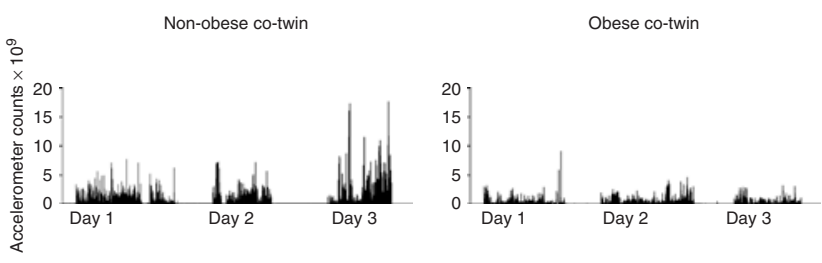

Figure 5 Accelerometer measurements during 3 days in a male monozygotic (MZ) obesity-discordant pair illustrating low overall and lack of high-intensity exercise in the obese co-twin.

when expressed per fat free mass, the daily BMRs of the co-twins were similar $(133 \pm 3 \mathrm{~kJ} / \mathrm{kg}$ in the obese vs. $129 \pm 5 \mathrm{~kJ} /$ $\mathrm{kg}$ in the non-obese, $P=0.24)$. The above BMR measures were similar in the co-twins of the weight-concordant twin pairs (data not shown).

Body weight correlated with BMR $(r=0.79, P=0.0001)$ and TEE $(r=0.66, P=0.003)$ in individual twins. Within twin pairs, weight differences were directly related to differences in BMR $(r=0.75, P=0.002)$. In a multiple regression model, intra-pair differences in fat $(\beta=11.9 \pm 4.6, P=0.020)$ and fatfree mass $(\beta=25.3 \pm 9.4, P=0.017)$ together explained most $\left(R^{2}=57 \%, P=0.0012\right)$ of the intra-pair difference in BMR. Differences in body composition did not explain the differences in TEE $\left(R^{2}=15 \%, P=0.67\right)$, which was closely linked to accelerometer counts in individual twins $(r=0.56, P=0.013)$. Accelerometer counts correlated also closely with AEE $(r=$ $0.68, P=0.004)$, AEE $/ \mathrm{kg}$ body weight $(r=0.79, P=0.002)$ and PAL $(r=0.62, P=0.015)$.

\section{DISCUSSION}

This study, covering the transition period from adolescence to young adulthood, shows that the risk for developing adult overall obesity (OR 3.9) and especially abdominal obesity (OR 4.8) was significantly increased in physically inactive adolescents. Self-perceived poor fitness in adolescence also captured the high risk for overall (5.1) and abdominal obesity (3.2) in adulthood. The risk excess was evident independent of genetic effects, as shown by the substudy in MZ twins discordant for adult obesity. Once obesity was established, habitual PA remained extremely low, denoting low energy expenditure. These findings provide cogent evidence that a sedentary lifestyle in adolescence triggers the development of obesity, which may lead to a self-perpetuating vicious circle of less activity, low energy expenditure and increasing adiposity. 
Previous results on the relationship between PA and weight trajectories in youth have been inconsistent. A decline in PA during adolescence (1) has been related to increase in adiposity at $18-19$ years in a cohort of black and white girls from the United States (2). Females from the 1958 British cohort who were physically active at 16 years showed a slower gain in BMI between 16 and 45 years than less active females, whereas the reverse was found for males (4). In previous Finnish studies, decreasing activity between adolescence and adulthood rather than adolescent inactivity has been associated with adult obesity risk $(5,6)$. In the present study, it was clear that persistent PA in adolescence prevents adult obesity.

We were also able to show, for the first time, that PA in adolescence helps prevent adult abdominal obesity above and beyond its effect on overall obesity. The risk for abdominal obesity in the persistently inactive group was substantial after adjustment for both adolescent (OR 5.7) and adult BMI (OR 4.8). The previous Finnish study showed weaker similar trends (OR 1.8) with decreasing PA in females (6).

An observation that some people find it both easy to exercise and maintain a healthy weight, has led to a suggestion that PA and body composition share a common genetic background. The Quebec Family Study showed that habitual PA was more genetically determined than sports participation, and suggested that the propensity toward being spontaneously active could be partly influenced by the genotype (30). Levine et al. (31) came to a similar conclusion with a completely different study design, in a study of 10 obese and 10 non-obese volunteers who wore activity sensors for 10 days to measure body postures and movements. Obese individuals were found to be sitting down, on average, for $2 \mathrm{~h}$ longer daily than lean individuals. Posture allocation did not change when the obese individuals lost weight or when lean individuals gained weight, suggesting that the differences may be biologically determined. While not contradicting the evidence that genes are important, we have shown in an MZ co-twin control design that a sedentary lifestyle leads to obesity, independent of genetic factors.

Obese and non-obese co-twins in this study did not differ significantly for TEE or AEE. This may be explained by the fact that although obese people expend more energy in performing a given level of PA (11), they tend to move less and thus do not have increased total or activity energy expenditure (12). Accelerometer measurements demonstrated that the obese co-twins were only half as active overall as the nonobese co-twins (Figure 4) and avoided high intensity exercise bouts altogether (Figure 5). We therefore suggest that obese persons (even at a young age) easily fall below the level of PA that might be needed to maintain cardiovascular health. With the low overall level of PA, it is easy to understand that obese persons are extremely vulnerable to continuous weight gain.

Despite there being no differences found in TEE, BMR was significantly higher in twins with acquired obesity due to their larger body size. This is in line with previous studies showing that variations in resting metabolic rate following overfeeding or negative energy balance in MZ twins were accounted for primarily by the changes in body mass (32). Our study confirms that when expressed as per its main determinant, i.e., fat-free mass (33), BMR does not change in acquired obesity.

The strengths of our study include prospective longitudinal measurements of PA and BMI over a critical period from adolescence to adulthood. In a cross-sectional setting at 25 years, detailed and objective measures of PA, energy expenditure and body composition were used to enrich the prospective questionnaire data. Within MZ twin pairs, the relationships are free of potentially confounding genetic effects, which is a major strength of this study. The main limitations of the study include self-reported data in the entire population sample and a limited number of discordant pairs in the MZ clinical protocol with just 10 highly discordant MZ pairs, despite a population-based screening of five full birth cohorts of young adult twins. This itself is consistent with the evidence that obesity is significantly influenced by genetic factors.

In summary, this study underscores the causal role of low PA as a risk factor of obesity and especially abdominal obesity during the transition from adolescence to early adulthood. Further, our results show that a physically inactive lifestyle triggers weight gain and vice versa independent of genetic effects. Thus, when it comes to the vicious circle of physical inactivity and obesity, genes confer dispositions, not destinies (34).

\section{ACKNOWLEDGMENTS}

We thank Erjastiina Heikkinen, Katja Tuominen, and Mia Urjansson for their skillful assistance in the study. The study was supported by the National Institute on Alcohol Abuse and Alcoholism (grants AA-08315, AA-00145, and AA-12502), the European Union Fifth Framework Program (QLRT1999-00916, QLG2-CT-2002-01254), the Academy of Finland (grants 44069, 100499, and 201461), the Academy of Finland Centre of Excellence in Complex Disease Genetics, Helsinki University Central Hospital grants. Kirsi H. Pietiläinen is supported by the following foundations: Yrjö Jahnsson, Jalmari \& Rauha Ahokas, Juho Vainio, Finnish Cultural, Finnish Medical Foundation, and Research Foundation of the Orion Corporation. Aila Rissanen initiated the concept of the study and Aila Rissanen, Jaakko Kaprio, and Kirsi H. Pietiläinen designed it. Kirsi H. Pietiläinen conducted the trial and Aila Rissanen, Jaakko Kaprio, and Hannele Yki-Järvinen supervised its progression. Klaas R. Westerterp provided the DLW and accelerometer protocols and together with Guy Plasqui analyzed them. Kirsi H. Pietiläinen, Patrik Borg, Urho M. Kujala, and Jaakko Kaprio performed the statistical analyses. Kirsi H. Pietiläinen and Aila Rissanen drafted the manuscript. Richard J. Rose is the principal investigator of the FinnTwin16-25 study. All authors contributed to the conception of the paper and interpretation of data.

\section{DISCLOSURE}

The authors declared no conflict of interest.

(C) 2008 The Obesity Society

\section{REFERENCES}

1. Kimm SY, Glynn NW, Kriska AM et al. Decline in physical activity in black girls and white girls during adolescence. N Engl J Med 2002;347:709-715.

2. Kimm SY, Glynn NW, Obarzanek E et al. Relation between the changes in physical activity and body-mass index during adolescence: a multicentre longitudinal study. Lancet 2005;366:301-307.

3. Gordon-Larsen P, Adair LS, Nelson MC, Popkin BM. Five-year obesity incidence in the transition period between adolescence and adulthood: the National Longitudinal Study of Adolescent Health. Am J Clin Nutr 2004;80:569-575.

4. Parsons TJ, Manor O, Power C. Physical activity and change in body mass index from adolescence to mid-adulthood in the 1958 British cohort. Int J Epidemiol 2006;35:197-204. 
5. Yang X, Telama R, Viikari J, Raitakari OT. Risk of obesity in relation to physical activity tracking from youth to adulthood. Med Sci Sports Exerc 2006;38:919-925.

6. Tammelin T, Laitinen J, Nayha S. Change in the level of physical activity from adolescence into adulthood and obesity at the age of 31 years. Int $J$ Obes 2004;28:775-782.

7. Hasselstrøm H, Hansen SE, Froberg K, Andersen LB. Physical fitness and physical activity during adolescence as predictors of cardiovascular disease risk in young adulthood. Danish Youth and Sports Study. An eight-year follow-up study. Int J Sports Med 2002;23(Suppl 1):S27-S31.

8. Wareham NJ, van Sluijs EM, Ekelund U. Physical activity and obesity prevention: a review of the current evidence. Proc Nutr Soc 2005;64:229-247.

9. Beunen G, Thomis M. Genetic determinants of sports participation and daily physical activity. Int J Obes Relat Metab Disord 1999;23(Suppl 3):S55-S63.

10. Schousboe K, Willemsen G, Kyvik KO et al. Sex differences in heritability of BMI: a comparative study of results from twin studies in eight countries. Twin Res 2003;6:409-421.

11. Prentice AM, Black AE, Coward WA, Cole TJ. Energy expenditure in overweight and obese adults in affluent societies: an analysis of 319 doubly-labelled water measurements. Eur J Clin Nutr 1996;50:93-97.

12. Ferraro R, Boyce VL, Swinburn B, De Gregorio M, Ravussin E. Energy cost of physical activity on a metabolic ward in relationship to obesity. Am J Clin Nutr 1991;53:1368-1371.

13. Rising R, Harper IT, Fontvielle AM et al. Determinants of total daily energy expenditure: variability in physical activity. Am J Clin Nutr 1994;59:800-804.

14. Bouchard C, Perusse L, Deriaz O, Despres JP, Tremblay A. Genetic influences on energy expenditure in humans. Crit Rev Food Sci Nutr 1993;33:345-350.

15. Hewitt JK, Stunkard AJ, Carroll D, Sims J, Turner JR. A twin study approach towards understanding genetic contributors to body size and metabolic rate. Acta Genet Med Gemellol (Roma) 1991;40:133-146.

16. Kaprio J, Pulkkinen L, Rose RJ. Genetic and environmental factors in health-related behaviors: studies on Finnish twins and twin families. Twin Res 2002;5:366-371.

17. Pietiläinen KH, Rissanen A, Laamanen M et al. Growth patterns in young adult monozygotic twin pairs discordant and concordant for obesity. Twin Res 2004;7:421-429.

18. Pietiläinen $\mathrm{KH}$, Rissanen $\mathrm{A}$, Kaprio J et al. Acquired obesity is associated with increased liver fat, intra-abdominal fat, and insulin resistance in young adult monozygotic twins. Am J Physiol Endocrinol Metab 2005;288:E768-E774.
19. Cole TJ, Bellizzi MC, Flegal KM, Dietz WH. Establishing a standard definition for child overweight and obesity worldwide: international survey. BMJ 2000;320:1240-1243.

20. Lean ME, Han TS, Morrison CE. Waist circumference as a measure for indicating need for weight management. BMJ 1995;311:158-161.

21. Mazess RB, Barden HS, Bisek JP, Hanson J. Dual-energy x-ray absorptiometry for total-body and regional bone-mineral and soft-tissue composition. Am J Clin Nutr 1990;51:1106-1112.

22. Aarnio M, Winter T, Kujala U, Kaprio J. Associations of health related behaviour, social relationships, and health status with persistent physical activity and inactivity: a study of Finnish adolescent twins. Br J Sports Med 2002;36:360-364.

23. Plasqui G, Joosen AM, Kester AD, Goris AH, Westerterp KR. Measuring free-living energy expenditure and physical activity with triaxial accelerometry. Obes Res 2005;13:1363-1369.

24. Baecke JA, Burema J, Frijters JE. A short questionnaire for the measurement of habitual physical activity in epidemiological studies. Am J Clin Nutr 1982;36:936-942.

25. Kriska AM, Knowler WC, LaPorte RE et al. Development of questionnaire to examine relationship of physical activity and diabetes in Pima Indians. Diabetes Care 1990;13:401-411.

26. Ferrannini $\mathrm{E}$. The theoretical bases of indirect calorimetry: a review. Metabolism 1988;37:287-301.

27. Westerterp KR, Wouters L, van Marken Lichtenbelt WD. The Maastricht protocol for the measurement of body composition and energy expenditure with labeled water. Obes Res 1995;3(Suppl 1):49-57.

28. Westerterp KR. Energy metabolism and body composition: general principles. Eur Respir Mon 2003;24:1-10.

29. Rao JNK, Scott AJ. On chi-squared tests for multiway contingency tables with cell proportions estimated from survey data. Ann Stat 1984;12:46-60.

30. Pérusse L, Tremblay A, Leblanc C, Bouchard C. Genetic and environmental influences on level of habitual physical activity and exercise participation. Am J Epidemiol 1989;129:1012-1022.

31. Levine JA, Lanningham-Foster LM, McCrady SK et al. Interindividual variation in posture allocation: possible role in human obesity. Science 2005;307:584-586.

32. Bouchard C, Tremblay A. Genetic influences on the response of body fat and fat distribution to positive and negative energy balances in human identical twins. J Nutr 1997;127(Suppl 5):S943-S947.

33. Weyer C, Snitker S, Rising R, Bogardus C, Ravussin E. Determinants of energy expenditure and fuel utilization in man: effects of body composition, age, sex, ethnicity and glucose tolerance in 916 subjects. Int J Obes Relat Metab Disord 1999;23:715-722.

34. Rose RJ. Genes and human behavior. Annu Rev Psychol 1995;46:625-654. 